\title{
PREPARING TEACHERS FOR THE USE OF INTERACTIVE E-LEARNING EXERCISES
}

\author{
Iryna Vorotnykova ${ }^{1}$, Olga Zakhar ${ }^{2}$ \\ ${ }^{1}$ Borys Grinchenko Kyiv University (UKRAINE) \\ ${ }^{2}$ Mykolaiv In-Service Teachers Training Institute (UKRAINE)
}

\begin{abstract}
The article defines the basic conditions for preparing teachers to use interactive exercises in elearning. The analysis of the use of interactive electronic exercises by computer science teachers is carried out. Their list and directions of their use at different stages of the lesson are determined. An indicative plan for preparing teachers of different subjects for this activity is proposed. Computer science teachers and professors of postgraduate pedagogical education participated in the study.
\end{abstract}

Keywords: e-learning, interactive e-learning exercises, postgraduate education.

\section{INTRODUCTION}

In 2013 the European Commission published the Digital Competence Framework for Citizens. The document identifies five areas and 21 competencies, including the concept of digital literacy [1], and later defined recommendations for implementing that framework [2]. These documents draw attention to the need to prepare the public for the use of digital technologies for: information and data literacy, communication and collaboration, digital content creation, safety, problem solving. The knowledge society requires teachers to constantly develop their digital competence and introduce digital technology in their professional activities. Based on the exchange of experiences of teachers from different European countries, the latest version of the open consultations has been published, outlining 38 existing ICT practices and requirements for the digital competence of bDigComp teachers [3]. In 2017 the European Commission updated the digital competence framework for DigComp 2.1 [4], which is one of the latest European modern strategic documents today. The Digital Competence Education Standard (DigCompEdu) developed by the European Community of Countries is offered to teachers [5]. The content of these standards and the socialization of the society lead to the need for elearning, adaptive learning and the development and use of new formats and types of exercises.

The development of digital technologies contributes to the development of e-learning and new educational resources which are able to provide interactivity, collaboration, communication and problem solving. E-learning is an integral part of modern education [7]. Researchers are studying the critical factors that affect student satisfaction with e-learning, one of which is the quality of the elearning course and the exercises used in it [8]. People who self-regulate in their e-learning achieve more positive learning outcomes than people who do not exhibit self-regulating behavior in learning [9]. The use of interactive exercises in e-learning can help to increase cognitive interest, motivation and help shape the self-regulated behavior of learners.

Real-time applications (RTA) are most often implemented in clouds. Popular examples include, for instance, online multiplayer computer games, simulation-based e-learning, and real-time learning in virtual environments [11].

The rapid development of Web 2.0 technologies and cloud services enables you to select a variety of e-learning resources for e-learning and collaboration, communication and problem solving. An important factor in introducing online e-learning exercises is teachers' willingness to learn and use them. To ensure that interactive exercises are included in the educational process, the availability of devices and facilities for all e-learning participants is an important requirement. The research on the use of portable tools has identified that these tools are generally determined as being necessary in seven research topics: reading context, models of educational materials presentation, interactive behavior, education, e-learning, motor skills mastering and facilitating assisted learning [12].

The rapid development of digital technology has contributed to the popularity of e-learning. However, the e-learning environment is limited by the fact that instructors on the Internet cannot immediately control whether students remain focused in online-offline learning [13]. In our study, we are looking at 
those services and environments with interactive exercises that allow a teacher to be close to the students and support them in their learning.

Student-teacher interaction and student-student, student-content interaction in e-learning significantly enhance students' sense of affiliation and influence e-learning attachment and create a sense of commonality and belonging [14].

\section{METHODOLOGY}

The methods of research are theoretical: systematization and comparison of scientific provisions to introduce different elements of e-learning and modeling of advanced training concerning the use of interactive exercises in e-learning; empirical: observation, questionnaires of the teachers on the choice of interactive exercises for e-learning. The study involved 210 experts in computer science and 5 teachers of advanced training institutes. The research also used the opinion of 890 teachers who teach different subjects regarding digital technology learning needs and using it at the lessons.

\section{RESULTS}

Electronic educational resources are created with the use of information computer technologies and have electronic-digital form. They are reproduced on digital devices for educational purposes and are a set of educational means of digitization, in which interactivity is a necessary didactic property which performs certain didactic functions. Interactive learning tools (interactive exercises) are a set of technical and didactic tools that make it possible to activate the educational and cognitive activities of those who learn through the interaction of participants in the educational process during the interactivity.

The interactive dialogue is realized through the interaction of those who study with the software and hardware systems, which provides the user with the opportunity to choose the mode of operation, the content of the training material and to interact with other participants.

An interactive learning environment influences content perception, student satisfaction and selfefficacy. Through such environments, students learn self-regulation [15]. We define interactive electronic exercises as educational electronic information resources that realize the possibility of feedback in the process of collecting, processing, producing, transmitting educational information.

Let us consider what interactive tools are used in education.

\subsection{Analysis of the use of interactive exercises by computer science teachers}

In order to identify the needs and capabilities of teachers who teach different subjects for the use of interactive exercises in e-learning, first, a survey of computer science teachers who have a high level of digital competence and use a variety of computer programs and tools was conducted.

Most computer science teachers (95.2\%) identified that they require and use interactive exercises in lessons or in extracurricular activities "Fig.1" (project activities, STEM education, etc.).

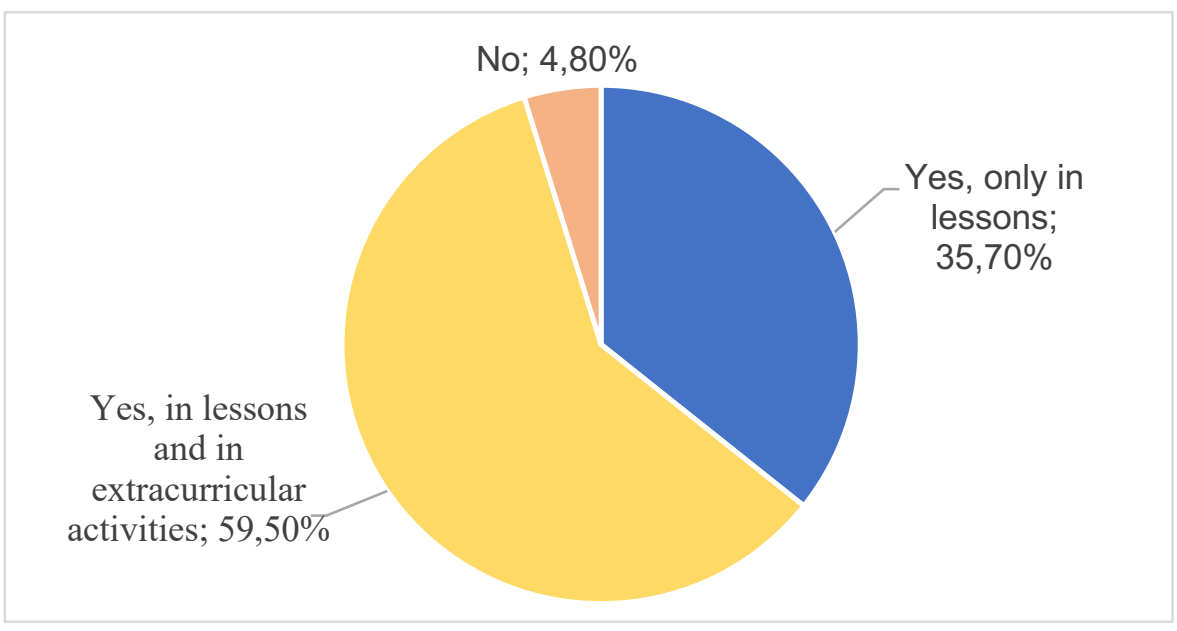

Figure 1. Computer science teachers' responses to the question "Do you use interactive exercises in e-learning?" 
Most of them (84.3\%) use the open source learningapps, which allow to use and create 19 types of exercises and contains a library of open educational electronic resources in many languages. Teachers also noted the need to use online quizzes Kahoot, Quizizz $(2.8 \%)$ test programs Plickers, Classtime $(1.9 \%)$ and interactive posters Thinglink (18.8\%) and interactive exercise books liveworksheet, wiser.my $(9 \%)$, interactive videos PlayPosit $(2.3 \%)$. The experience of computer science teachers has shown that interactive exercises contribute to attracting students and developing cognitive interest, organizing formative assessment, individualization and differentiation of learning, the ability to use elements of adaptive learning.

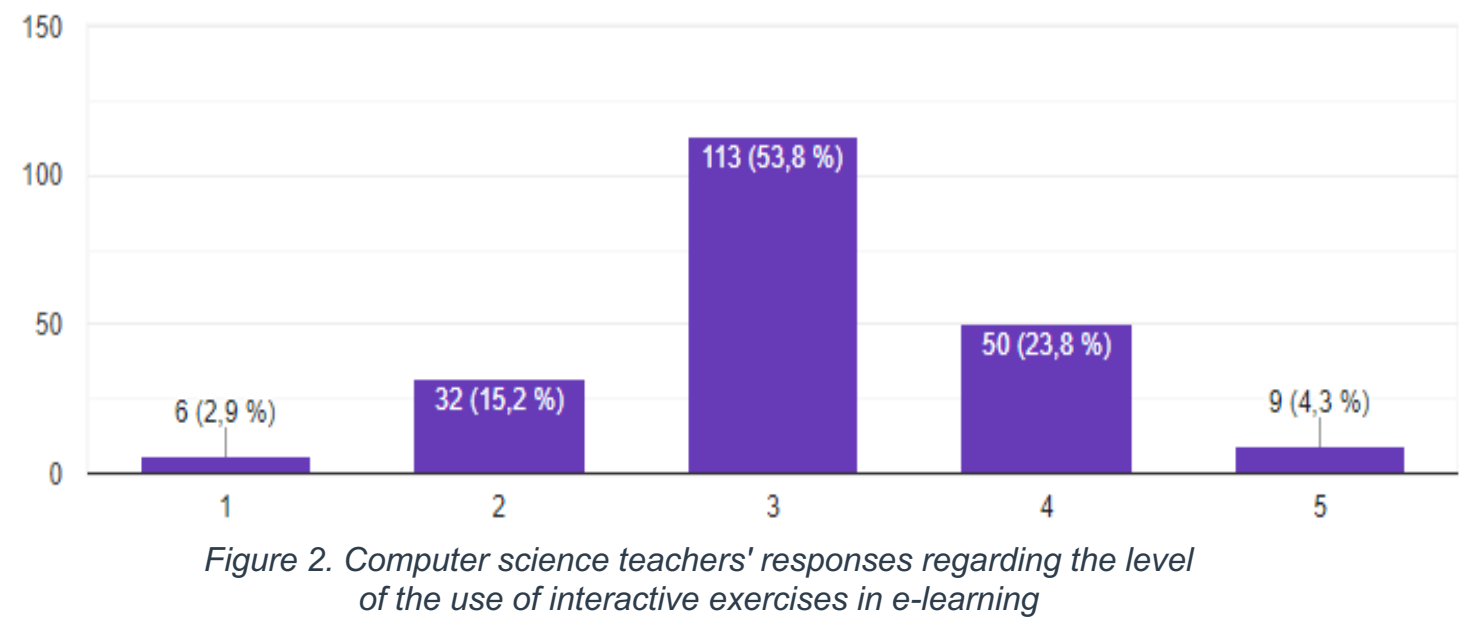

The results of teachers' self-assessment "Fig.2" show that most of them $(53.8 \%)$ do not consider themselves to be confident users of interactive exercise environments but use only their basic capabilities and libraries of these resources. Instead, it is more difficult for them to create and edit prepackaged resources. Only $4.3 \%$ of teachers are confident in how to create and use interactive exercises and are ready to teach other teachers. Among teachers who do not use interactive exercises, $2.9 \%$ said they needed to learn how to use them and were ready to master new digital tools.

The survey of computer science teachers showed the importance of introducing the topic of interactive electronic resources for professional development and advanced training.

According to computer science teachers, interactive electronic exercises implement active teaching methods, they can be used in class, remotely and using a mixed form of training for: organizing formative assessment, processing of educational material at an individual pace, presentation of educational content using different teaching styles, introduction of game technologies at lessons, organization of project activity, introduction of STEM education, cooperation and interaction of participants of educational process, automation of academic achievements.

\subsection{Areas of training teachers of different subjects for the introduction of interactive exercises in e-learning.}

The use of interactive exercises in the classroom is the use of special training programs that help complete the training material at your own pace, master it and pass the test.

Interactive exercises can be used not only in computer science lessons but also in other lessons. A survey of 890 teachers of different subjects in Kyiv identified 199 of them needing postgraduate digital education. Most of the teachers are interested in learning how to use ICT at lessons (78\%) and for professional development $(22 \%)$ and indicated the need to use interactive exercises.

Let us analyze the experience of the experts-teachers of postgraduate pedagogical education "Tabl.1" and the computer science teachers for the construction of educational modules for teachers who teach different subjects. Table 1 presents the ranking of services with interactive exercises for the use in the educational process by teachers who teach various subjects. 
Table 1. Experts' opinion on the introduction of interactive exercises in e-learning.

\begin{tabular}{|c|c|c|c|c|c|c|c|}
\hline & 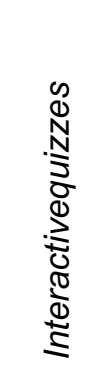 & 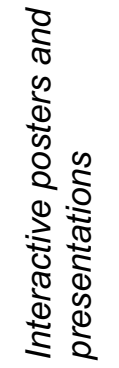 & 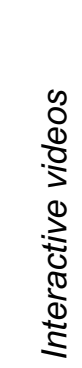 & 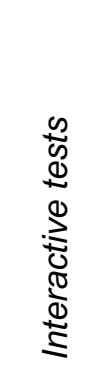 & 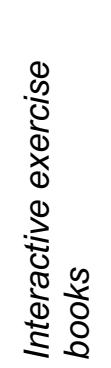 & 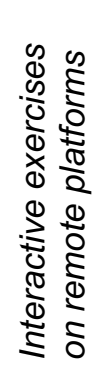 & 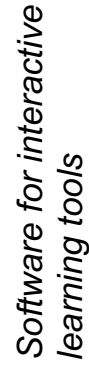 \\
\hline $\begin{array}{l}\text { eighted } \\
\text { ithmetic mean }\end{array}$ & 2.6 & 4.8 & 3.6 & 3.2 & 4 & 5.4 & 3.4 \\
\hline
\end{tabular}

The experts preferred interactive exercises on remote platforms and the use of interactive posters and presentations. Taking into account the opinion of the computer science teachers and the experts, we came to the conclusion that it is necessary to create several training modules to prepare teachers for the use of interactive exercises in the educational process.

For example, Institute of In-Service Teachers' Training of Borys Grinchenko Kyiv University and Mykolaiv In-Service Teachers Training Institute created an educational program "Methods of using interactive educational electronic resources" which includes educational modules for teachers of different subjects:

- Creating and using interactive presentations, quizzes, videos, notebooks, posters (learningapps, Kahoot, EDpuzzle, Studystack, Mentimeter, thinglink, wizer.me)

- Technology for creating an e-guide "Overview of various e-tutorial methods and resources, approaches to generating interactive content (Ispring Free, Flip pdf, ExeBook Self-Publisher, web designers, etc.).

- Creating training videos and infographics: creating training videos (PowerPoint, Powtoon, Openshot), interactive videos (YouTube, Playposit, EDpuzzle) and infographics (Canva, Easel.ly, Venngage).

- Creating didactic materials for the use with the interactive whiteboard.

- Creating interactive exercises in remote modules (Edmodo, Moodle, Google Class).

Advanced training course participants not only master the environments that are new for them, but also create interactive exercises for their lessons, exchange experience of their usage. The teachers who completed the training in these modules (150 people) gave a positive assessment of their content $(96 \%)$ and started using interactive exercises in the classroom, $4 \%$ indicated the impossibility of introducing interactive exercises as an element of e-learning in the absence of digital devices (interactive whiteboard, projector, computer) in their classrooms.

The main conditions for preparing teachers for the use of interactive exercises in postgraduate education are the following: readiness and motivation of teachers to use the elements of e-learning in lessons, educational policy in the field of e-learning introduction, hardware and software for postgraduate education, availability of interactive e-exercises for e-learning and methodological guidelines for their use; ergonomics (sanitary standards for the use of interactive e-exercises for elearning), scientific and methodological support, post-training teacher consulting (training and education programs and modules, generalization of teacher experience, etc.), teacher training through interactive exercises and e-learning.

\section{CONCLUSIONS}

Digitizing education requires a change in approaches to educational resources and is a prerequisite for the introduction of proactive methods and techniques, including in e-learning. The European Union approaches to shaping the information culture of the society and the requirements for teachers' digital competence contribute to changing teaching methods, introducing online collaboration and communication practices, using ICT to automate the learning process and workflow, problem solving [1], [2], [4], [5]. 
The analysis of the responses of computer science teachers suggests that teachers who have the ability to use gadgets in class have experience in using interactive posters, quizzes, games, tests, notebooks, presentations.

Teachers' self-assessment of the use of interactive electronic presentations showed their willingness to learn more about the methods of using interactive tools.

Determining the areas of using interactive electronic exercises in class, interviewing teachers of different subjects and taking into account the opinions of experts who work in postgraduate pedagogical education, allowed to identify the main topics and directions of teacher training for this activity.

Potential criteria for success in learning stem from the general characteristics of the teaching system, the success of using information systems, including interactive exercises and expert interviews can be divided into: system quality, content quality, and service or support quality [15]. Teachers' satisfaction and the use of interactive exercises in their professional activities are indicators of the success of their preparation for the introduction of e-learning.

The introduction of training modules on the use of interactive e-exercises for the implementation of elearning in the system of postgraduate pedagogical education allowed to determine under what conditions it is possible: educational policy in education and a specific institution, the use of e-learning, hardware and software, availability of interactive exercises for e-learning and methodological guidelines for their use, sanitary standards and scientific and methodological support for teacher training (educational programs and developed modules, summarizing the experience of teachers, etc.).To further our research, we intend to introduce interactive e-exercises in teachers' professional activities and analyse the experience of using them to share experiences and provide quality education.

\section{REFERENCES}

[1] S. Carretero, R. Vuorikari, Yv. Punie, "The Digital Competence Framework for Citizens", Publications Office of the European Union, 2017, doi:10.2760/38842.

[2] S. Kluzer, G. Rissola, "Guidelines on the adoption of DigComp", Telecenter Europe Dec/2015, 2015. Retrieved from URL: https://all-digital.org/wp-content/uploads/2015/12/TE-Guidelines-onthe-adoption-of-DIGCOMP_Dec2015.pdf

[3] S. Kluzer and L. P. Priego, “DigComp into action: Get inspired, make it happen. A user guide to the European Digital Competence Framework (No. JRC110624)", Joint Research Centre (Seville site). 2018. Retrieved from URL. DOI:10.2760/112945.

[4] DigComp 2.1: The Digital Competence Framework for Citizens. Update Phase 1: the Conceptual Reference Model, Luxembourg: Publications Office of the European Union. 2017. doi:10.2760/38842.

[5] C. Redecker, "European framework for the digital competence of educators: DigCompEdu (No. JRC107466)", Joint Research Centre (Seville site). 2017. Retrieved from URL: https://ec.europa.eu/jrc/en/publication/eur-scientific-and-technical-research-reports/europeanframework-digital-competence-educators-digcompedu.

[6] J. Boon, E. Rusman, M. Van der Klink, and C. Tattersall, "Developing a critical view on e-learning trend reports: trend watching or trend setting?", International journal of training and development, no. 9(3), pp. 205-211, 2005.

[7] D.R. Garrison, "E-learning in the 21st century: A framework for research and practice". Routledge, 2011.

[8] P.Ch. Sun, et al. "What drives a successful e-Learning? An empirical investigation of the critical factors influencing learner satisfaction", Computers \& education, no.50.4, pp.1183-1202, 2008.

[9] L. Barnard-Brak, V. O. Paton, William Yun Lan, "Profiles in self-regulated learning in the online learning environment", The International Review of Research in Open and Distributed Learning, no.11(1), pp. 61-80, 2010.

[10] L. Bengt-Åke (ed.), "National systems of innovation: Toward a theory of innovation and interactive learning". Anthem press, vol. 2, 2010. 
[11] C.M. Chen, J. Y. Wang, and C. M. Yu, "Assessing the attention levels of students by using a novel attention aware system based on brainwave signals," (in English), British Journal of Educational Technology, Article vol. 48, no. 2, pp. 348-369, Mar 2017, doi: 10.1111/bjet.12359.

[12] D. Meilander and S. Gorlatch, "Modeling the Scalability of Real-Time Online Interactive Applications on Clouds," Future Generation Computer Systems-the International Journal of Escience, vol. 86, pp. 1019-1031, Sep 2018, doi: 10.1016/j.future.2017.07.041.

[13] J.H. Xu and B.C. Zhong, "Review on portable EEG technology in educational research," (in English), Computers in Human Behavior, Review vol. 81, pp. 340-349, Apr 2018, doi: 10.1016/j.chb.2017.12.037.

[14] N. Luo, M.L. Zhang, and D. Qi, "Effects of different interactions on students' sense of community in e-learning environment," (in English), Computers \& Education, Article vol. 115, pp. 153-160, Dec 2017, doi: 10.1016/j.compedu.2017.08.006.

[15] G.M. Kim and S.M. Ong, "An exploratory study of factors influencing m-learning success," (in English), Journal of Computer Information Systems, Article vol. 46, no. 1, pp. 92-97, 2005. 